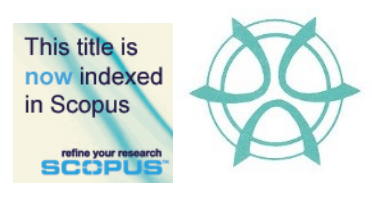

PLANNING MALAYSIA:

Journal of the Malaysian Institute of Planners

VOLUME 19 ISSUE 1 (2021), Page 127 - 137

\title{
CULTURALMAPPING AND HERITAGE TRAIL IN KUALA KANGSAR
}

\author{
Nor Mazlan Mohd Yunus ${ }^{1}$, Esmawee Endut ${ }^{2}$, Shahrul Yani Said ${ }^{3}$ \\ ${ }^{1,2,3}$ Faculty of Architecture, Planning and Surveying, \\ UNIVERSITI TEKNOLOGI MARA, SHAH ALAM
}

\begin{abstract}
Kuala Kangsar is the Royal Town of Negeri Perak. It was established in the 1720s. The name Kuala Kangsar is believed to be derived from the kangsar plant (Hibiscus flocussus) that grows in abundance along the banks of the Sungai Kangsar. Another strong suggestion claims that the name was handed down by explorers and settlers who had established a settlement at the mouth of the river. They called their new home Kuala Kurang Sa, a short form for Kuala Kurang Seratus because there were 99 tributaries that flowed into the Sungai Perak around the area. Kuala Kangsar became famous and remarkable not only because of its title as a royal town but also for its heritage and historical factors. There are a lot of heritage assets in this area. Because of these reasons, Kuala Kangsar has become popular and appealing to attract more tourists. This paper will identify and classify the heritage assets in Kuala Kangsar. The identifications and classifications will be based on some methods which consist of site familiarisation, unstructured interviews, visual observation and literature reviews. After heritage assets identification is done, this paper will develop the Cultural Mapping for Kuala Kangsar where Cultural Mapping is a tool to illustrate all the heritage assets' location and position in mapping and graphics. Finally, this paper will introduce the Heritage Trail to link all these heritage assets in Kuala Kangsar.
\end{abstract}

Keywords: Heritage Assets Identification, Cultural Mapping and Heritage Trail

${ }^{1}$ Corresponding Author. Email: normazlan@kpkt.gov.my 
Nor Mazlan Mohd Yunus, Esmawee Endut, Shahrul Yani Said

Cultural Mapping and Heritage Trail in Kuala Kangsar

\section{INTRODUCTION}

When Sultan Idris Murshidul'adzam Shah (1877-1916) ascended the throne, he selected a site on Bukit Chandan to build his palace, thus becoming the first in a line of sultans to live at Bukit Chandan and be buried on the west side of the Sungai Perak. His palace, completed in 1895, was named Istana Negara. The royal ambience that characterises Kuala Kangsar started to take shape with the high ground at Bukit Chandan as its focal point. A townhouse for the Sultan, Istana Kota, was completed in 1903. It was also known as Istana Hulu, as it was upstream from Istana Negara. Today, this palace houses the Sultan Azlan Shah Gallery. The wooden Istana Kenangan, built in 1926, was used as the royal palace while Istana Iskandariah was being constructed to replace Istana Negara. A number of other palaces occupied by various members of the royal family dot Kuala Kangsar, including the Istana Chinta Berahi and Istana Kasar Ma'amor, which were built by Sultan Idris for his two wives. Istana Bendahara was the residence of the last Raja Bendahara of Perak, a son of Sultan Idris. In 1906, two newly completed houses of the Sultan at Bukit Chandan became the first houses in Kuala Kangsar to be lit with electricity, which was powered by a power station located at Bukit Chandan itself (Dr. Neil Khor, 2017). Kuala Kangsar has a lot of heritage assets to be recognised and appreciated. This paper will identify the heritage assets in Kuala Kangsar before developing the Cultural Mapping and Heritage Trail in order to ensure that all these assets are connected with each other.

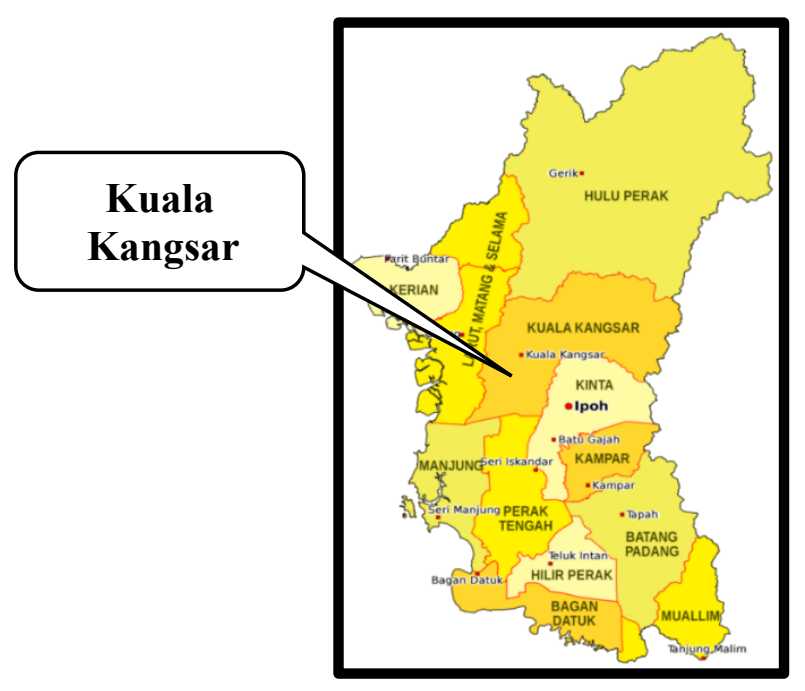

Figure 1: Location Plan of Kuala Kangsar, Negeri Perak 


\section{Heritage Assets Identification, Cultural Mapping and Heritage Trail}

Heritage assets is defined as assets of historical, or scientific importance that are held to advance preservation, and educational objectives of charities, and through public access contribute to the national culture and education either at national or local level. Such assets are central to the achievement of the purposes of such charities and include the land, buildings, structures, collections, exhibits or artefacts that are preserved or conserved and are central to the educational objectives of such charities (Russell, 2006).

The identicafion of heritage assets in Kuala Kangsar is an exercise which will involve several steps such as site visit, visual observation, the collection of secondary data from literature reviews, and a few unstructured interviews if needed. Based on this approach, heritage assets in Kuala Kangsar can be identified effectively.

As for Cultural Mapping, it is a process of collecting, recording, analysing and synthesizing information in order to describe the cultural resources, networks, links and patterns of usage of a given community or group (Stewart, 2010). In this paper, the Cultural Mapping will be developed after identification of heritage assets in Kuala Kangsar is completed. The purpose of a Cultural Mapping is to ensure that all heritage assets are being connected with each other and presented in infographic. Based on this approach, the heritage assets full of cultural resources and characters will be compiled together and well-connected with each other.

Then finally, creating the Heritage Trail which is a designated journey that brings the trail explorer to learn more about a country's history, culture, architecture, flora and fauna by visiting historical sites and buildings (National Heritage Board Singapore, 2004) is part of the output of this paper. A Heritage Trail is being created in order to construct a journey through a series of historical and heritage sites with the aim of observing and discovering the area. Exploration of a Heritage Trail can be done on foot or by vehicles. For Kuala Kangsar, a Heritage Trail is quite important and significant in order to connect all the heritage assets in this area. Furthermore, the heritage assets are dispersed and located separately.

\section{Heritage Assets Identification in Kuala Kangsar}

Based on visual observation, site familiarisation, secondary data collection from literature reviews and unstructured interviews, 22 heritage assets in Kuala Kangsar have been identified as listed in the table below:

Table 1: Heritage Assets Identification in Kuala Kangsar

\begin{tabular}{c|l|c}
\hline No. & Heritage Assets & Remarks \\
\hline 1. & Masjid Ubudiah & Mosque \\
\hline 2. & Istana Kenangan & Palace \\
\hline
\end{tabular}


Nor Mazlan Mohd Yunus, Esmawee Endut, Shahrul Yani Said

Cultural Mapping and Heritage Trail in Kuala Kangsar

\begin{tabular}{|c|c|c|}
\hline 3. & Istana Iskandariah & Palace \\
\hline 4. & Local handicraft & Gold Embroidery \\
\hline 5. & Local handicraft & $\begin{array}{l}\text { Malay Traditional } \\
\text { Weapon }\end{array}$ \\
\hline 6. & Baitul Annur & Mansion \\
\hline 7. & Baitul Rahmah & Mansion \\
\hline 8. & King's Pavilion & School \\
\hline 9. & Perak War Memorial & Cemetery \\
\hline 10. & Sultan Azlan Shah Gallery & Gallery \\
\hline 11. & The Oldest Rubber Tree in Malaysia & Tree \\
\hline 12. & Malay College Kuala Kangsar & School \\
\hline 13. & Pavilion Tower & Monument \\
\hline 14. & Labu Sayong & Local Handicraft \\
\hline 15. & Makam Sultan Ali Al-Mukammal Inayat Shah & Mausoleum \\
\hline 16. & Makam Sultan Yusuf Sharifuddin Mudzaffar Shah & Mausoleum \\
\hline 17. & Rumah Kutai in Kg. Sayong Lembah & Malay Traditional House \\
\hline 18. & $\begin{array}{llllll}\text { Tomb Stone of Sultan Mansur Shah } & 1 & @ \\
\text { Masjid } & \text { Kota Lama Kanan } & & & \\
\end{array}$ & Tomb Stone \\
\hline 19. & Iskandar Bridge & Bridge \\
\hline 20. & Victoria Bridge & Bridge \\
\hline 21. & Air Raid Shelter & Fort \\
\hline 22. & Tok Setia's Mansion & Mansion \\
\hline
\end{tabular}

This paper managed to identify the heritage assets in Kuala Kangsar. There are 22 heritage assets consisting of buildings, palaces, rubber tree, institutions, mausoleums, monuments and handicrafts. These heritage assets can be promoted and can boost Kuala Kangsar as a heritage site and tourism destination. These heritage assets have their own potential and strength to promote Kuala Kangsar to become a good destination for heritage and conservation enthusiasts and lovers. The location of each heritage asset in Kuala Kangsar is presented in Figure 2 below: 


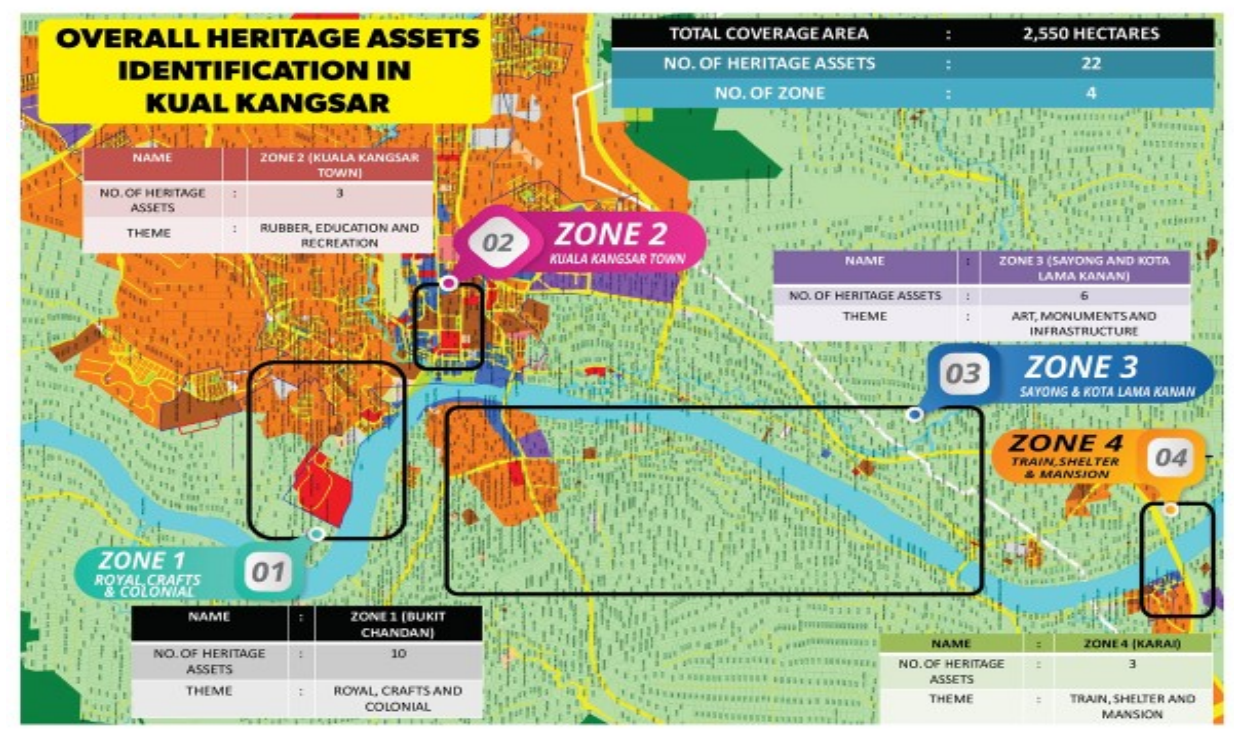

Figure 2: Location of Heritage Assets in Kuala Kangsar, Negeri Perak

\section{Development of Cultural Mapping for Kuala Kangsar}

Cultural mapping is a process of collecting, recording, analysing and synthesizing information in order to describe the cultural resources, networks, links and patterns of usage of a given community or group (Stewart, 2010).

Cultural mapping is widely recognized as an effective tool for development and planning. Mapping makes culture more visible so that it can be utilised in new ways such as exchanged, linked and further developed (Young, 2003).

Cultural mapping has been recognized by United Nations Educational, Scientific and Cultural Organisation (UNESCO) as a crucial tool and technique in preserving the world's intangible and tangible cultural assets. It encompasses a wide range of techniques and activities from community-based participatory data collection and management to sophisticated mapping using Geography Information System (GIS) (UNESCO).

Cultural mapping is a methodology that can also support an interpretation of space. At both individual and collective levels, it is a means to locate yourself in the world "physically, culturally, and psychologically" as well as politically. It provides a means to consider day-to-day realities, and provides a possibility to question this reality and generate an improved understanding of the cultural context. Mapping processes provide ways to interact creatively with urban reality, to uncover and articulate diverse perspectives, and to generate unique meanings and value that can be shared (Duxbury N. G.-P., 2015). 
Nor Mazlan Mohd Yunus, Esmawee Endut, Shahrul Yani Said

Cultural Mapping and Heritage Trail in Kuala Kangsar

The purpose and usage of Cultural Mapping is mentioned in the table as below:

Table 2: The Purpose and Usage of Cultural Mapping

\begin{tabular}{|c|c|c|}
\hline No. & Uses & Explanation \\
\hline 1. & $\begin{array}{l}\text { Increasing knowledge } \\
\text { and appreciation }\end{array}$ & $\begin{array}{l}\text { Helping to define the local culture. Demonstrating } \\
\text { the breadth and variety of cultural activity in the } \\
\text { municipality. }\end{array}$ \\
\hline 2. & $\begin{array}{l}\text { Identifying previously } \\
\text { unknown resources } \\
\text { and activities }\end{array}$ & $\begin{array}{l}\text { Providing concise information to elected officials, } \\
\text { tourist groups, branches of municipal government, the } \\
\text { general public and other stakeholders. Advocating for } \\
\text { and drawing attention to the cultural area. }\end{array}$ \\
\hline 3. & $\begin{array}{l}\text { Getting a fresh } \\
\text { perspective }\end{array}$ & $\begin{array}{l}\text { Looking at data from different points of view, cross- } \\
\text { cultural, public access, concentration and networking. }\end{array}$ \\
\hline 4. & $\begin{array}{l}\text { Gaining objectivity } \\
\text { and overview }\end{array}$ & $\begin{array}{l}\text { Going from intuitive or anecdotal information from the } \\
\text { "worm's-eye view" on the ground, to a broader, more } \\
\text { concrete view. Seeing around discipline-based and siloed } \\
\text { viewpoints. }\end{array}$ \\
\hline 5. & $\begin{array}{l}\text { Identifying networks } \\
\text { and hubs }\end{array}$ & $\begin{array}{l}\text { Where do groups obtain their resources, how do they } \\
\text { communicate with one another, and who are the } \\
\text { liaisons? }\end{array}$ \\
\hline 6. & $\begin{array}{l}\text { Locating gaps, needs } \\
\text { and overlaps }\end{array}$ & $\begin{array}{l}\text { How much duplication or scarcity is there in a } \\
\text { given sector or area of the city. }\end{array}$ \\
\hline 7. & $\begin{array}{l}\text { Is the distribution of } \\
\text { resources effective? }\end{array}$ & $\begin{array}{l}\text { How far does a population group have to travel to } \\
\text { borrow a book or hold a meeting? Where can a } \\
\text { Chinese dance troupe find a qualified instructor? }\end{array}$ \\
\hline 8. & Evaluating Projects & $\begin{array}{l}\text { How large is the population served? How does the } \\
\text { community view an initiative? Does a solution respond } \\
\text { adequately to the problem? }\end{array}$ \\
\hline 9. & $\begin{array}{l}\text { Seeing the present, } \\
\text { looking to the future }\end{array}$ & $\begin{array}{l}\text { How many informal community hubs will that new } \\
\text { expressway disrupt? What will be the impact of an } \\
\text { influx of mmigration from Southeast Asia on the } \\
\text { existing community and its resources? }\end{array}$ \\
\hline 10. & Cultural planning & $\begin{array}{l}\text { Mapping is often the first stage of preparing a } \\
\text { cultural plan. }\end{array}$ \\
\hline
\end{tabular}

Source: (Stewart, 2010)

This paper also will explore the practices of establishing the Cultural Mapping in Canada, Portugal and Asia (Nepal and Thailand). The main purpose is to identify the similarities and divergences of practices among three different localities. Based on this exploration, the similarities and differences will be translated in detail in the table below:

Table 3: Stages of Cultural Mapping Preparation Practices in Canada, Portugal and Asia

\begin{tabular}{|c|c|c|}
\hline Canada & Portugal & $\begin{array}{c}\text { Asian (Nepal and } \\
\text { Thailand) }\end{array}$ \\
\hline
\end{tabular}




\begin{tabular}{|c|c|c|}
\hline $\begin{array}{l}\text { 1. Planning } \\
\text { a. Determine } \\
\text { Objectives } \\
\text { b. State Objectives } \\
\text { c. Set Parameters } \\
\text { d. Estimate } \\
\text { Readiness } \\
\text { e. Assemble } \\
\text { Resources } \\
\text { 2. Project Design } \\
\text { a. Frame the } \\
\text { Fundamental } \\
\text { Question } \\
\text { b. The Inventory } \\
\text { c. Design Survey } \\
\text { and Interview } \\
\text { Questions } \\
\text { Implementation } \\
\text { Explore } \\
\text { a. Contacting the } \\
\text { Community } \\
\text { b. Tallying Entering } \\
\text { Results } \\
\text { 4ynthesis Make } \\
\text { Sense } \\
\text { a. Roughing Out } \\
\text { the Maps } \\
\text { b. Converting an } \\
\text { Inventory to } \\
\text { Map } \\
\text { c. Analysis and } \\
\text { Interpretation } \\
\text { 5. Finalising the Map } \\
\text { a. Speaking to } \\
\text { Different } \\
\text { Audiences } \\
\text { Going Public } \\
\text { a. Getting the } \\
\text { World Out }\end{array}$ & $\begin{array}{l}\text { 1. Identification of } \\
\text { Tangible Assets } \\
\text { 2. Engaging Community } \\
\text { Members } \\
\text { 3. Cultural Information } \\
\text { Data Collection, } \\
\text { Analyse and Synthesis } \\
\text { 4. Produce A Multi- } \\
\text { layered Picture } \\
\text { 5. Involvement of } \\
\text { Activists, Residents, } \\
\text { Researches and } \\
\text { Political Dimensions } \\
\text { 6. Establishment of } \\
\text { Framework for } \\
\text { Cultural Mapping }\end{array}$ & $\begin{array}{l}\text { 1. Identify the Heritage } \\
\text { Assets, Intangible and } \\
\text { Tangible } \\
\text { 2. Establish A Broad } \\
\text { Framework of Ideas } \\
\text { and Practices } \\
\text { 3. Community } \\
\text { involvements and } \\
\text { Empowerments } \\
\text { 4. Protection of } \\
\text { Human Rights and } \\
\text { Respecting the } \\
\text { Traditional } \\
\text { Knowledge }\end{array}$ \\
\hline
\end{tabular}

This paper has investigated three practices in preparation of Cultural Mapping which are from Canada, Portugal and Asia. The Canada practices are very detailed and particular when designing the Cultural Mapping stages and steps. They have six stages in preparing the Cultural Mapping and every stage have their own steps. Among the three practices, Canada's is better and more effective in terms of preparing Cultural Mapping. They determine the objectives, design 
Nor Mazlan Mohd Yunus, Esmawee Endut, Shahrul Yani Said

Cultural Mapping and Heritage Trail in Kuala Kangsar

the project, explore the implementation, conduct synthesis, finalise the map and promote the map to the public.

From the Portugal perspective, they are also concerned about the community's involvement but they prefer to identify the assets first, especially tangible assets. Then they proceed to data collection, and next they produce a multi-layered picture and establish the framework of Cultural Mapping. Based on the Portugal practices, they are very particular with public participation and also activists, researches and political influence. These situations have proved the importance of Cultural Mapping to be in line with public needs and to garner a bit of political will. Finally, the Cultural Mapping projects are able to fulfil the people's needs from the heritage sites.

When this research looked into the Asian practices specifically in Nepal and Thailand, it was found that they are also concerned with the identification of heritage assets for both types of assets which are tangible and intangible. Then they proceed to establish the framework of ideas and practices, and allow the public to participate in this exercise for them to share and exchange their views and opinions. For Asian practices, they also consider the protection of human rights and respecting the traditional knowledge. This aspect is very significant and outstanding compare to the other two practices. Maybe for the Asian society, there is a stronger need to protect and more concern on human rights and traditional knowledge which are in line with Asian customs and cultures. For the Asian practice, the number of stages is less than Portugal and Canada, which is four stages only. Portugal and Canada have six stages in practice of preparing for Cultural Mapping in their country, and among the two, Canada is more detailed and comprehensive.

Cultural Mapping is the method and platform to identify the heritage assets on the site, inventorise all assets, connect them, produce the profiles, highlight their strength, potential and also weakness, and finally approach the community to get their feedbacks and responses. These principles and keywords can be used for designing and producing the Cultural Mapping for Kuala Kangsar. The elements, contents and items of the stages and steps can be duplicated in the Kuala Kangsar context and practise. Perhaps these stages and steps can help develop the best Cultural Mapping of Kuala Kangsar in line with complimenteng the public needs with the appreciation of heritage assets in Kuala Kangsar.

\section{Establishment of Cultural Mapping for Kuala Kangsar}

This paper will develop a Cultural Mapping of Kuala Kangsar. In order to ensure that heritage assets will be managed properly, besides identifying them, this paper also included them in the Cultural Mapping. Based on this mapping, all the assets are connected each other and a Heritage Trail will be used as a mechanism to 
achieve the purpose and approach. This paper will illustrate how the Heritage Trail will be implemented and constructed. This paper managed to generate the table of stages in preparing the Cultural Mapping, propose the Cultural Mapping illustrations and lastly propose a Heritage Trail for Kuala Kangsar as shown in the table and maps below:

Table 4: The Proposed of Stages in Preparing a Cultural Mapping for Kuala Kangsar

\begin{tabular}{|c|c|c|}
\hline No. & $\begin{array}{c}\text { The Stages in Preparing a Cultural } \\
\text { Mapping for Kuala Kangsar }\end{array}$ & Justification \\
\hline 1. & $\begin{array}{l}\text { Planning and Designing the Objectives } \\
\text { and Framework }\end{array}$ & $\begin{array}{l}\text { To ensure that the Cultural Mapping is } \\
\text { totally useful and practicable. }\end{array}$ \\
\hline 2. & $\begin{array}{l}\text { Identification of the Heritage Assets, Both } \\
\text { Tangible and Intangible }\end{array}$ & $\begin{array}{l}\text { To produce the inventory and profile } \\
\text { for all heritage assets in all heritage } \\
\text { sites. }\end{array}$ \\
\hline 3. & $\begin{array}{l}\text { Establishment of Heritage Assets } \\
\text { Database }\end{array}$ & $\begin{array}{l}\text { This inventory and profile will } \\
\text { become a database and reference for } \\
\text { any parties in relation to the } \\
\text { conservation of the heritage assets. }\end{array}$ \\
\hline 4. & Involvement and & $\begin{array}{l}\text { To create a sense of belonging and } \\
\text { ownership amongst the local residents } \\
\text { and to reduce the burden on the } \\
\text { government side. }\end{array}$ \\
\hline 5. & $\begin{array}{lrc}\text { Protection of } & \text { Human } & \text { Rights and } \\
\text { Respecting the } & \text { Traditional Knowledge }\end{array}$ & $\begin{array}{l}\text { Some heritage assets especially intangible } \\
\text { heritage will have values to our culture, } \\
\text { custom and civilisation. }\end{array}$ \\
\hline 6. & $\begin{array}{l}\text { Producing the Cultural Mapping into } \\
\text { Pictures, Infographics and User-Friendly } \\
\text { Mapping }\end{array}$ & $\begin{array}{l}\text { To create and produce the most interesting, } \\
\text { attractive and practical Cultural Mapping } \\
\text { in the future. }\end{array}$ \\
\hline
\end{tabular}


Nor Mazlan Mohd Yunus, Esmawee Endut, Shahrul Yani Said

Cultural Mapping and Heritage Trail in Kuala Kangsar

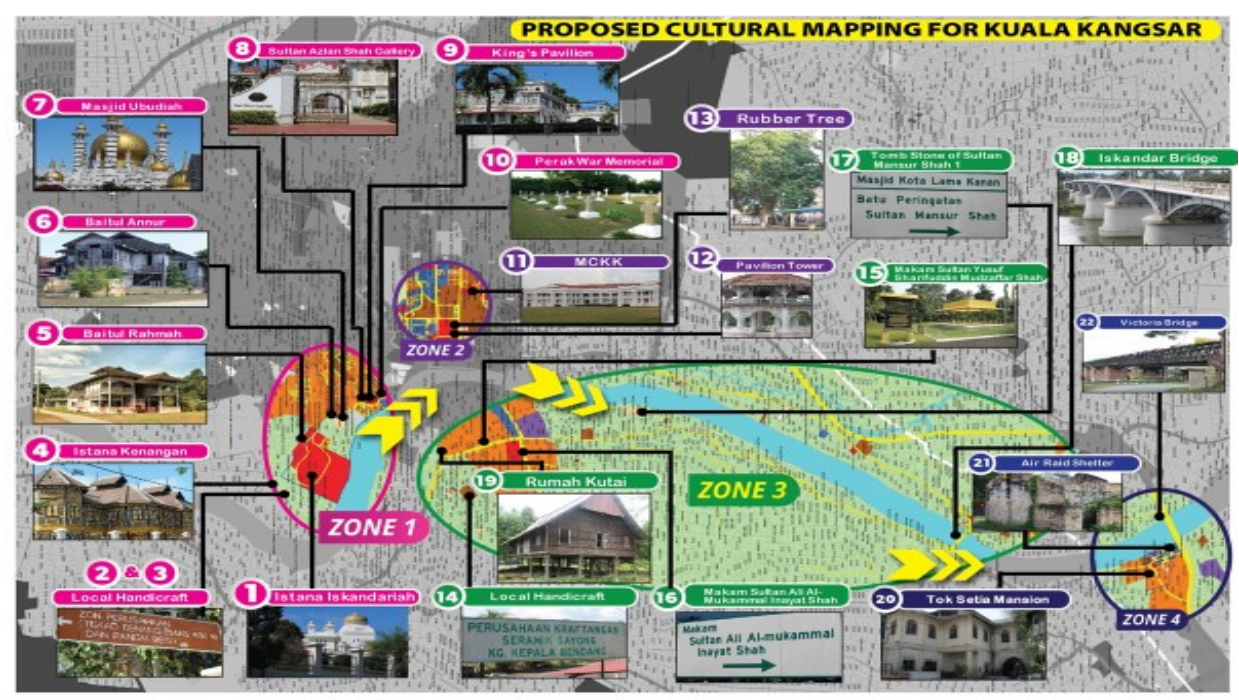

Figure 3: Proposed Cultural Mapping for Kuala Kangsar

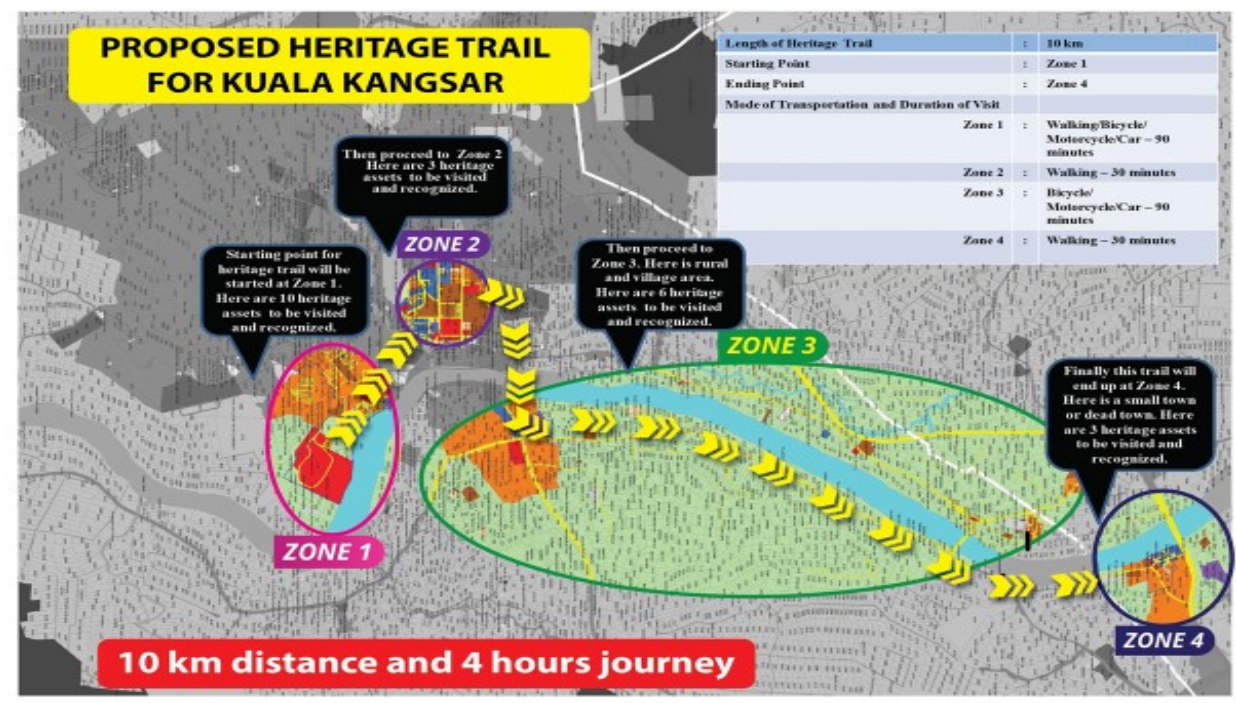

Figure 4: Proposed Heritage Trail for Kuala Kangsar

\section{CONCLUSION}

In this paper, there are three major aspects that have been acknowledged and explored which are the identification of heritage assets in Kuala Kangsar, the development of a Cultural Mapping for Kuala Kangsar and finally the proposed 
heritage trail for Kuala Kangsar. This paper managed to identify 22 heritage assets in Kuala Kangsar based on visual observation, site visits, secondary data collections and unstructured interviews. These heritage assets are consisting of buildings, palaces, the oldest rubber tree, institutions, mausoleums, monuments and handicrafts. These heritage assets can be promoted to boost yje attraction of Kuala Kangsar as a heritage site and tourism destination. Besides identifying the heritage assets in Kuala Kangsar, this paper has also managed to develop the Cultural Mapping for Kuala Kangsar. This paper has analysed three Cultural Mapping practices which are in Canada, Portugal and Asia (Nepal and Thailand). Based on this analysis, this paper found that there are six stages that need to be implemented in preparing the Cultural Mapping for Kuala Kangsar. These are the best practices to be carried out for the development of the Cultural Mapping for Kuala Kangsar. At the same time, in order to ensure that all heritage assets will be manageable and connected properly, a Heritage Trail has been introduced as a mechanism to achieve the purpose.

\section{REFERENCES}

Dr. Neil Khor, M. I. (2017). The Towns of Malaysia : An Illustrated Urban History of the Peninsula up to 1957. Kuala Lumpur: Editions Didier Millet Sdn. Bhd.

Duxbury, N. G.-P. (2015). Cultural Mapping as Cultural Inquiry. New York: Routledge Advances in Research Methods Series.

National Heritage Board Singapore. (2004). Guidelines on Designing Heritage Trail. Singapore: National Heritage Board Singapore.

Russell, D. (2006). Heritage Assets : Can Accounting Do Better? London: Accounting Standard Boards.

Stewart, S. (2010). Cultural Mapping Tool Kit : A Partnership between 2010 Legacies Now and Creative City Network of Canada. Canada: Creative City Network of Canada.

Taylor, K. (2013). Cultural Mapping : Intangible Values and Engaging with Communities with Some Reference to Asia.

UNESCO. (n.d.). Cultural Mapping. Paris.

Young, G. (2003). Cultural Mapping in The Global World. ASEAN Committee on Culture and Information. Australia.

Received: $15^{\text {th }}$ February 2021. Accepted: $10^{\text {th }}$ May 2021 